\title{
Lactation and body weight of dairy cows: interrelationships among heat stress, calving season and milk yield ${ }^{*}$
}

\author{
E. Maltz ${ }^{1}$, O. Kroll ${ }^{2}$, H. Barash ${ }^{3}$, A. Shamy \\ and N. Silanikove $\mathrm{e}^{3,4}$ \\ 'Institute of Agricultural Engineering, Agricultural Research Organization, The Volcani Center \\ P.O. Box 6, Bet Dagan 50 250. Israel \\ 'Hahaklait, Mutual Society for Cattle Insurance, and Veterinary Services in Israel Lid. \\ 20 bareket St. Zone 24. P.O. Box 3039, Caesarea Industrial Park, 38900, Israel \\ ${ }^{3.4}$ Institute of Animal Science, Agricultural Research Organization. The Volcani Center \\ P.O. Box 6, Bet Dagan 50 250, Israel
}

(Received 3 November 1999; accepted 13 January 2000)

\begin{abstract}
How the interactions among heat stress, calving season and milk yield (MY) affects lactation and body weight (BW) curves was studied by analyzing the daily records of MY and BW of dairy cows. The summer calving cows (SC) attained minimal BW sooner than winter calving cows (WC), the differences between ligh yielding ( $\mathrm{HY} ; \mathrm{MY} \geq 40 \mathrm{l} / \mathrm{d}$ ) SC and WC bcing greatcr than differences between low yielding ( $\mathrm{LY} ; \mathrm{MY}<40 \mathrm{l} / \mathrm{d}$ ). The minimal $\mathrm{BW}$ was lower in all $\mathrm{SC}$ than in $\mathrm{WC}$ and this could be related to the differences between the HY cows. MY peak was higher in all WC than in all SC, similar in LY cows among the two treatments, and higher in HY WC than in HY SC. The 4.4\% differences in MY during the first $40 \mathrm{wk}$ postpartum between all WC (8960 1) and all SC (8568) could be related to $8.0 \%$ differences between HY WC (10444l) and HY SC (9604 l). During the summer peak MY occurred later than during the winter irrespective of the production level. We have shown that heat stress during early lactation affects the entire lactation and BW curves in dairy cows, and that heat stress negatively interacts with MY.
\end{abstract}

KEY WORDS: dairy cows, heat stress, calving season, milk yield

* Contribution from the Agricultural Research Organization, Institute of Agricultural Engineering, Bet Dagan, Israel, No 736/99

4 Corresponding author 


\section{INTRODUCTION}

The summers in the tropical and sub-tropical belts on earth are hot and long. The cattle in the tropical and subtropical regions of the earth are exposed to extend periods of heat stress (3-6 months each year). The vulnerability of dairy cows to heat stress is reflected by depressed milk yield, feed intake and reproductive performance (Collier et al., 1982; Beede and Collier, 1986). The prevailing view is that the reduction of milk yield under heat stress is the consequence of reduced appetite (Collier et al., 1982; Beede and Collier, 1986; Armstrong, 1994; West, 1994). However, this view is challenged by evidences for a direct relationship between heat stress and the process of milk secretion (Wayman et al., 1962; Bandanrannayaka and Holmes, 1976; Barash et al., 1996). Force-feeding of hyperthermic cows to the level recorded in normothermic cows (Wayman et al., 1962), or restricting the intake of normothermic cows to the level recorded in hyperthermic cows (Bandanrannayaka and Holmes, 1976), did not abolished the differences in milk yield between normothermic and hyperthermic cows. More recently, Barash et al. (1996) found by analyzing the Israeli national records that the lowest annual milk yield of Holsteins occurs in cows that are giving birth during the summer. Dairy cows are exposed to approximately same duration of heat stress irrespective of their calving month. Thus, the fact that the lowest yields are recorded in cows calving during the summer means that the detrimental effect of heat stress at this stage is more pronounce than in any other stage of the lactation. Involution followed by preparation of the udder secretory capacity occurs during late pregnancy, and mamogenesis continues during the early stage of lactation (Knight and Wilde, 1993). Therefore, obstruction of such process by heat stress may modify the optimal development of milk secretion, hence the shape of the lactation curve. Obstruction of the secretion capacity of the udder may also modify the homeorhetic distribution of metabolisable energy between the udder non-secreting tissues; hence, the pattern of the post partum changes in body weight. However, we are not aware to previous efforts to compare the lactation and body weight curves of summerand winter calving cows.

Higher milk yield increases the overall thermal load on the cows because of increased metabolic heat production. Enhancing milk yield through the use of bovine somatotropin in cows subjected to heat stressed increased the cows hyperthermia (West, 1994). However, these experiments were carried out so far with relatively low producing cows and were not associated with detrimental effects on milk yield. The average yield of milk by cows in Israel (Israel Cattle Breeders Association, 1997) is the highest in Europe, and comparable to the top records in the USA. Therefore, if heat stress negatively interact with milk yield, its effects should be pronounced under the Israeli conditions.

The long-term effects of the interactions among calving season and production potential on the shape of the lactation and BW curves has not been studied. 
The objective of this study was to determine the existence and magnitude of such effects by using on-line daily records of milk yield and BW data from a control study carried out in an Israeli commercial dairy farm.

\section{MATERIAL AND METHODS}

The data analyzed in this study are based on thrice daily recording of milk yield and BW from one Israeli dairy farm (Kibbutz Alumim) between the years 1988-1989 and 1994-1995. This farm is located on the border between the north of the Negev desert and the inner coast lowland, with annual rainfall of $350 \mathrm{~mm}$ only during winter months. The environmental conditions were collected in a near by meteorological station and are described in Figure 1. Cows participating in this analysis, were control cows in experiments involving cow fed by computer controlled self feeders (Maltz et al., 1991), and cows transfer between feeding groups compared to controls fed a flat rate TMR (Kroll et al., 1997). Therefore, these cows were fed a similar TMR in both periods and all year round.

The cows in both periods were fed a typical Israeli TMR throughout lactation, which was composed, of $62.5 \%$ concentrates and $35.5 \%$ high-quality roughages. The concentrates ingredients (DM\%) were: wheat grain, 4.3 ; shredded maize, 10.9; soyabean meal, 4.5 ; wheat bran, 6.1 ; cottonseeds, 4.5 ; gluten, 1.8 ; fish meal, 0.7 ; protected fat, 0.3 ; yeast, 0.2 , distillery dark grain, 3.6; crushed barley, 19.7. The main ingredients of the roughages were (\%): maize silage, 13.6; wheat silage, 15.0; vetch hay, 8.9 . Vitamin and mineral mixtures $(5.9 \%)$ were added to meet the NRC (1989) requirements. These rations contained $17 \%$ crude protein, 32 to $35 \% \mathrm{NDF}, 1.73 \mathrm{Mcal} / \mathrm{kg}$ NEL. Cows were milked 3 times daily at 0600,1400 and $2000 \mathrm{~h}$, and feed was distributed twice daily, after the morning milking and at 1600. Electronic milk meters (Bau Matic, DEC Inc., Madison, Wisconsin) monitored daily milk production. The cows were weighed after each milking by electronic walk-through scales located on outlet path of the milking parlor (Peiper et al., 1993). During the summer, as a daily routine, the cows were brought to the milking parlor waiting area between the morning and noon millings and forced cooled by a combination of shower wetting for $2 \mathrm{~min}$ and ventilation of $5 \mathrm{~min}$. This procedure was repeated successively 2 times between morning and noon milking, and noon and night milking.

The cows from second parity and above that calved between April to August were considered as summer calving cows (SC), and cows calving between November and March were considered as winter calving cows (WC). The data of fresh cows and of cows calving during the transitional season (September-October) were not included. The cows were divided between high yielding and low 
yielding according to the median milk yield. Cows with $M Y>401 / \mathrm{d}$ were classified as high yielding (HY) cows, whereas cows with $M Y<401 / d$ were classified as low yielding (LY) cows. Only cows that accomplished at least $40 \mathrm{wk}$ in lactation with no apparent health problems were included in the data analysis. The data set contained 51 cows during 1988-1989, and 52 cows during 1994-1995. Their distribution according to calving season, potential, and calving season $\mathrm{X}$ MY is described in Tables 1 and 2.

The analysis model was:

$$
\mathrm{Y}_{\mathrm{ijkl}}=\mathrm{S}_{\mathrm{i}}+\mathrm{HY}_{\mathrm{j}}+\mathrm{MYP}_{\mathrm{k}}+\mathrm{e}_{\mathrm{ijk}} \text {, }
$$

where:

$$
\begin{aligned}
& Y_{i j k}=\text { the compared variable (i.e. either milk yield, or } B W \text { ) } \\
& H Y_{j}=\text { effect of year, } j \\
& S_{i}=\text { effect of season, } i \\
& M Y P_{k}=\text { effect of milk yield potential, } k \\
& e_{i j k s}=\text { random residual effect. }
\end{aligned}
$$

\begin{tabular}{|c|c|c|c|c|c|c|c|c|c|c|c|}
\hline \multirow[t]{2}{*}{$\begin{array}{l}\text { Calving season } \\
\text { and production } \\
\text { potential }\end{array}$} & \multirow[t]{2}{*}{$\mathrm{n}$} & \multicolumn{2}{|c|}{$\begin{array}{c}\text { Post calving } \\
\text { weight }\end{array}$} & \multicolumn{2}{|c|}{$\begin{array}{c}\text { Minimal } \\
\mathrm{BW} \\
\mathrm{kg}\end{array}$} & \multicolumn{2}{|c|}{$\begin{array}{c}\triangle \mathrm{BW} \\
\text { at week } \\
40^{2}\end{array}$} & \multicolumn{2}{|c|}{$\begin{array}{l}\text { Week of } \\
\text { minimal } \\
\text { BW }\end{array}$} & \multicolumn{2}{|c|}{$\begin{array}{c}\text { Ascending } \\
\text { weight gain } \\
\text { kg/week }\end{array}$} \\
\hline & & $\mathrm{x}$ & SD & $x$ & SD & $x$ & SD & $x$ & $\mathrm{SD}$ & $\mathrm{x}$ & SD \\
\hline Summer, all cows & 52 & 578 & 61 & 536 & 52 & 65 & 6.4 & 5.6 & 3.4 & 2.8 & 1.2 \\
\hline Winter, all cows & 51 & 605 & 58 & 555 & 57 & 32 & 3.3 & 8.0 & 3.8 & 2.2 & 1.2 \\
\hline $\mathrm{P}<$ & & \multicolumn{2}{|c|}{0.05} & \multicolumn{2}{|c|}{0.05} & \multicolumn{2}{|c|}{0.0001} & \multicolumn{2}{|c|}{0.001} & \multicolumn{2}{|c|}{0.01} \\
\hline Summer, LP cows & 34 & 558 & 57 & 536 & 52 & 99 & 7.7 & 5.4 & 3.6 & 3.1 & 1.1 \\
\hline Winter, LP cows & 30 & 574 & 61 & 538 & 57 & 56 & 5.2 & 7.3 & 4.9 & 2.9 & 1.1 \\
\hline $\mathrm{P}<$ & & \multicolumn{2}{|c|}{ NS } & \multicolumn{2}{|c|}{ NS } & \multicolumn{2}{|c|}{0.01} & \multicolumn{2}{|c|}{0.05} & \multicolumn{2}{|c|}{0.01} \\
\hline Summer, HP cows & 18 & 594 & 51 & 544 & 48 & 37 & 4.2 & 5.8 & 2.9 & 2.2 & 1.2 \\
\hline Winter, HP cows & 21 & 624 & 48 & 577 & 48 & 18 & 3.1 & 9.0 & 4.5 & 2.0 & 0.9 \\
\hline $\mathrm{P}<$ & & \multicolumn{2}{|c|}{0.05} & \multicolumn{2}{|c|}{0.01} & & 0.01 & \multicolumn{2}{|c|}{0.01} & \multicolumn{2}{|c|}{ NS } \\
\hline
\end{tabular}

All the effects were class effects; the herd-year was defined from January through December of each year. Differences were sorted out by F-test using the PROC GLM of SAS (1988).

TABLE 1

Effect of calving scason and production potential on kinetics of body weight (BW) during lactation 
TABLE 2

Effect of calving season and production potential on milk yield and lactation kinetics

\begin{tabular}{|c|c|c|c|c|c|c|c|c|c|}
\hline \multirow[t]{2}{*}{$\begin{array}{l}\text { Calving season } \\
\text { and production } \\
\text { polential' }\end{array}$} & \multirow[t]{2}{*}{$\mathrm{n}$} & \multicolumn{2}{|c|}{$\begin{array}{c}\text { Peak milk } \\
\text { yield }\end{array}$} & \multicolumn{2}{|c|}{$\begin{array}{c}\text { Average } \\
\text { milk yield } \\
\text { l/day }\end{array}$} & \multicolumn{2}{|c|}{$\begin{array}{l}\text { Milk yield } \\
\text { decline }^{2}\end{array}$} & \multicolumn{2}{|c|}{$\begin{array}{c}\text { Time of } \\
\text { maximal yicld } \\
\text { week }\end{array}$} \\
\hline & & $x$ & SD & $\mathrm{x}$ & SD & $\mathrm{x}$ & SD & $\mathrm{x}$ & SD \\
\hline Summer, all cows & 52 & 38.2 & 3.2 & 30.6 & 4.6 & 0.41 & 0.1 & 13.0 & 5.6 \\
\hline Winter, all cows & 51 & 40.3 & 5.0 & 32.0 & 4.8 & 0.48 & 0.1 & 10.0 & 3.8 \\
\hline $\mathrm{P}<$ & & \multicolumn{2}{|c|}{0.001} & \multicolumn{2}{|c|}{0.01} & \multicolumn{2}{|c|}{0.05} & \multicolumn{2}{|c|}{0.01} \\
\hline Summer, LP cows & 34 & 35.0 & 3.4 & 28.6 & 3.5 & 0.36 & 0.1 & 14.6 & 6.6 \\
\hline Winter, LP cows & 30 & 35.5 & 2.9 & 28.3 & 2.7 & 0.40 & 0.1 & 11.2 & 5.5 \\
\hline $\mathrm{P}<$ & & \multicolumn{2}{|c|}{ NS } & \multicolumn{2}{|c|}{ NS } & \multicolumn{2}{|c|}{0.01} & \multicolumn{2}{|c|}{0.05} \\
\hline Summer, HP cows & 18 & 44.3 & 3.9 & 34.3 & 4.1 & 0.49 & 0.2 & 10.1 & 6.1 \\
\hline Winter, HP cows & 21 & 47.2 & 5.1 & 37.3 & 4.5 & 0.59 & 0.2 & 8.2 & 4.5 \\
\hline $\mathrm{P}<$ & & \multicolumn{2}{|c|}{0.005} & \multicolumn{2}{|c|}{0.01} & \multicolumn{2}{|c|}{ NS } & \multicolumn{2}{|c|}{0.05} \\
\hline
\end{tabular}

1 LP - cows produced at peak lactation less then $40 \mathrm{l} / \mathrm{d}$ on week average; HP - cows produced at peak lactation $40 \mathrm{l} / \mathrm{d}$ or more on week average.

2 descending slope from peak until weck 40 milk yield

\section{RESULTS}

\section{General}

Maximal ambient temperatures were above the upper critical temperature of $24^{\circ} \mathrm{C}$ (Berman et al., 1985) during the summer, and well below the upper critical temperature during the winter (Figure 1). During July, August and September the average minimal ambient temperatures $\left(22^{\circ} \mathrm{C}\right)$ were close to the upper critical temperature. This suggests that cows had difficulty dissipating the excess heat loads even during the night hours.

\section{Body weight}

The post-parturition BW (initial BW) of all cows calving during the summer was lower than in all cows calving during the winter (Table 1). The initial BW of LY SC was similar to those of the WC, whereas the initial BW of $\mathrm{HY}$ SC was lower than those of the HY WC (Table 1). Thus, the differences between all SC and all WC in initial BW can be related to the differences between the HY SC 


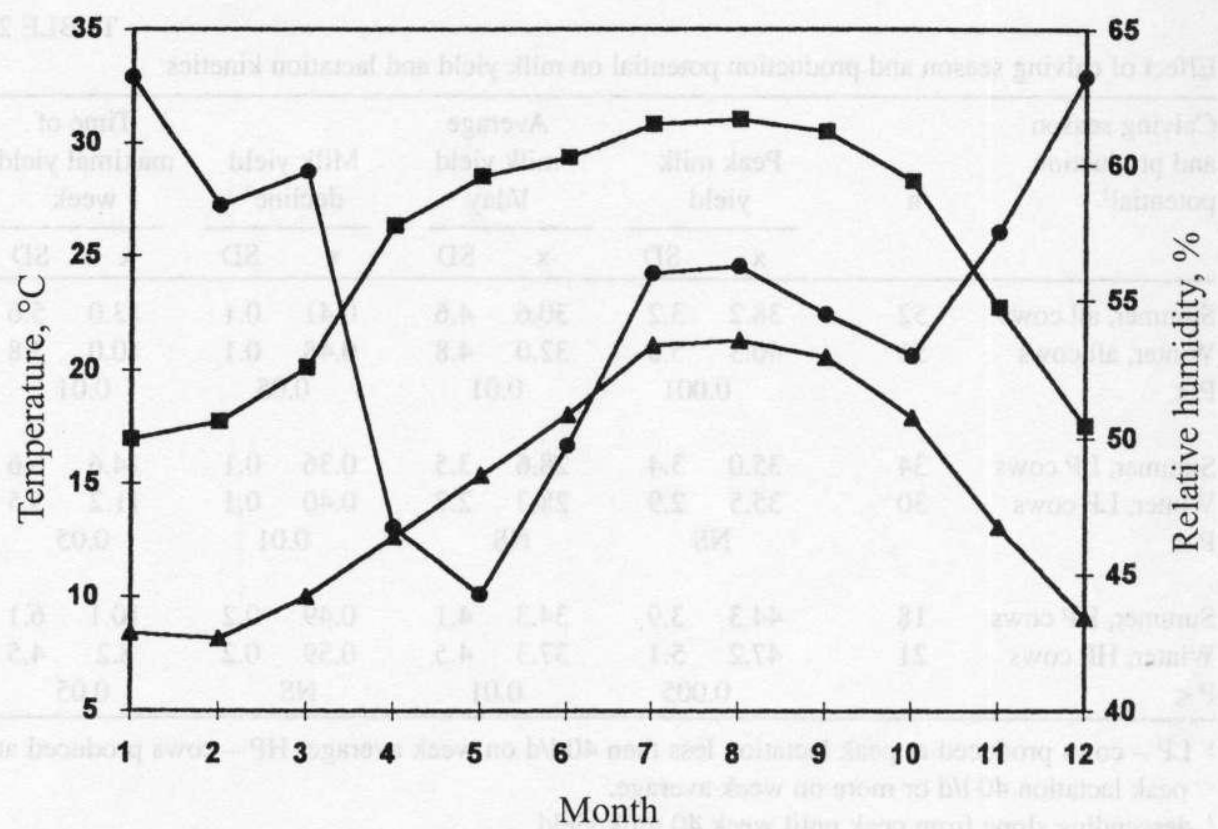

Figure 1. Average monthly environmental conditions during the trial. Relative humidity - $(\bullet)$, minimal ambient temperature $-\mathbf{\Lambda}$, maximal ambient temperature -

and WC. HY cows lost more BW than LY cows $(\mathrm{P}<0.05)$, however, there were no seasonal differences in this respect. Thus, as for the initial BW, the differences in minimal BW between all SC and all WC can be related to the differences between the HY cows (Table 2). Cows calving during the summer attained minimal BW sooner than cows calving during the winter (Table 1, Figure 2), the differences between HY SC and WC being greater than differences between LY cows (Table 1, Figure 2). The slope of the increase in BW after attaining minimal BW (ascending slope of BW) was higher $(\mathrm{P}<0.01)$ in LY cows than in HY cows. The ascending slope of BW in all SC was higher than in all WC, and in LY SC than in LY WC, but not between HY cows (Table 1). Thus, the differences in ascending slope of BW between all SC and all WC can be related to the differences between the LY cows. The increase in $\mathrm{BW}$ for the period elapsing between parturition and wk $40(\triangle \mathrm{BW}$ at wk 40$)$ was higher in all SC than in all WC (Table 1). The differences in $\triangle \mathrm{BW}$ between LY SC and WC were greater $(\mathrm{P}<0.01)$ than between HY SC and WC because in the former it reflected the combination of earlier recovery of $\mathrm{BW}$ and greater ascending slope whereas in the HY cows it reflected only earlier recovery in BW. 

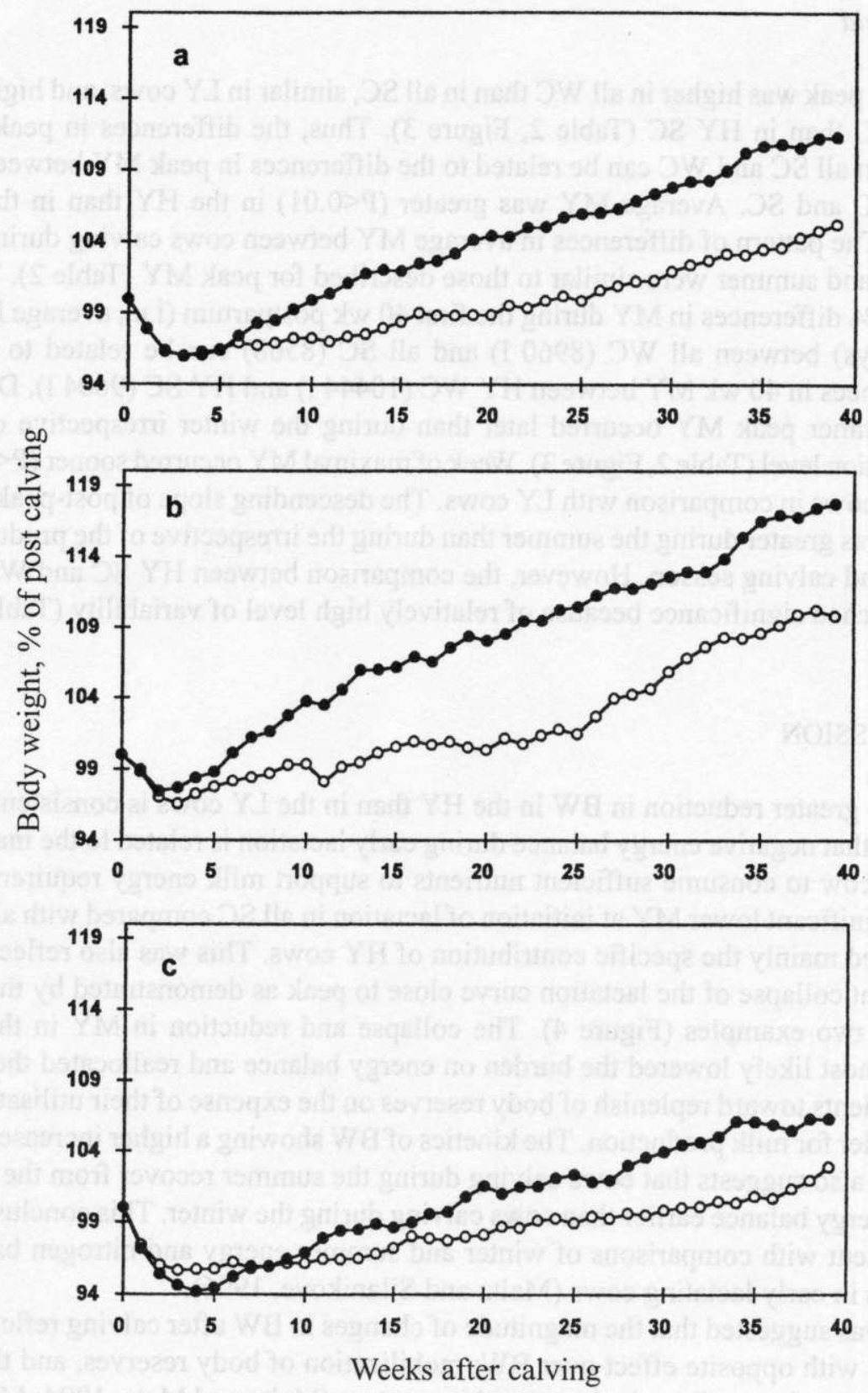

Figure 2. Body weight curves of summer (filled symbols) and winter (open symbols) calving cows. $\mathrm{a}$ - all cows, $\mathrm{b}$ - low yielding cows producing less then $40 \mathrm{l} / \mathrm{d}$ at peak on weekly average, $\mathrm{c}$ - high yielding cows producing $40 \mathrm{l} / \mathrm{d}$ or more at peak on weekly average 


\section{Milk yield}

MY peak was higher in all WC than in all SC, similar in LY cows, and higher in HY WC than in HY SC (Table 2, Figure 3). Thus, the differences in peak MY between all SC and WC can be related to the differences in peak MY between the HY WC and SC. Average MY was greater $(\mathrm{P}<0.01)$ in the HY than in the LY cows. The pattern of differences in average MY between cows calving during the winter and summer were similar to those described for peak MY (Table 2). Thus, the $4.4 \%$ differences in MY during the first 40 wk postpartum (i.e., average MY x 280 days) between all WC (8960 l) and all SC (8568) can be related to $8.0 \%$ differences in 40 wk MY between HY WC (10444 l) and HY SC (9604 l). During the summer peak MY occurred later than during the winter irrespective of the production level (Table 2, Figure 3). Week of maximal MY occurred sooner $(\mathrm{P}<0.05)$ in HY cows in comparison with LY cows. The descending slope of post-peak milk yield was greater during the summer than during the irrespective of the production level and calving season. However, the comparison between HY SC and WC did not reached significance because of relatively high level of variability (Table 2 ).

\section{DISCUSSION}

The greater reduction in BW in the HY than in the LY cows is consistent with notion that negative energy balance during early lactation is related to the inability of the cow to consume sufficient nutrients to support milk energy requirements. The significant lower MY at initiation of lactation in all SC compared with all WC reflected mainly the specific contribution of HY cows. This was also reflected in frequent collapse of the lactation curve close to peak as demonstrated by the presented two examples (Figure 4). The collapse and reduction in MY in the HY cows most likely lowered the burden on energy balance and reallocated the flow of nutrients toward replenish of body reserves on the expense of their utilisation in the udder for milk production. The kinetics of BW showing a higher increase slope for SC also suggests that cows calving during the summer recover from the negative energy balance earlier than cows calving during the winter. This conclusion is consistent with comparisons of winter and summer energy and nitrogen balance studies in early lactating cows (Maltz and Silanikove, 1996).

It was suggested that the magnitude of changes in BW after calving reflect two factors with opposite effect over BW: mobilization of body reserves, and the enlargement of gastrointestinal tract and its content (Maltz and Metz, 1994; Maltz et al., 1997). This was confirmed by direct measurements (Bahaa et al., 1998a,b). The kinetics of BW, in this study, suggests that HY and LY cows calving during the summer respond differently to the environmental conditions. HY SC exper- 

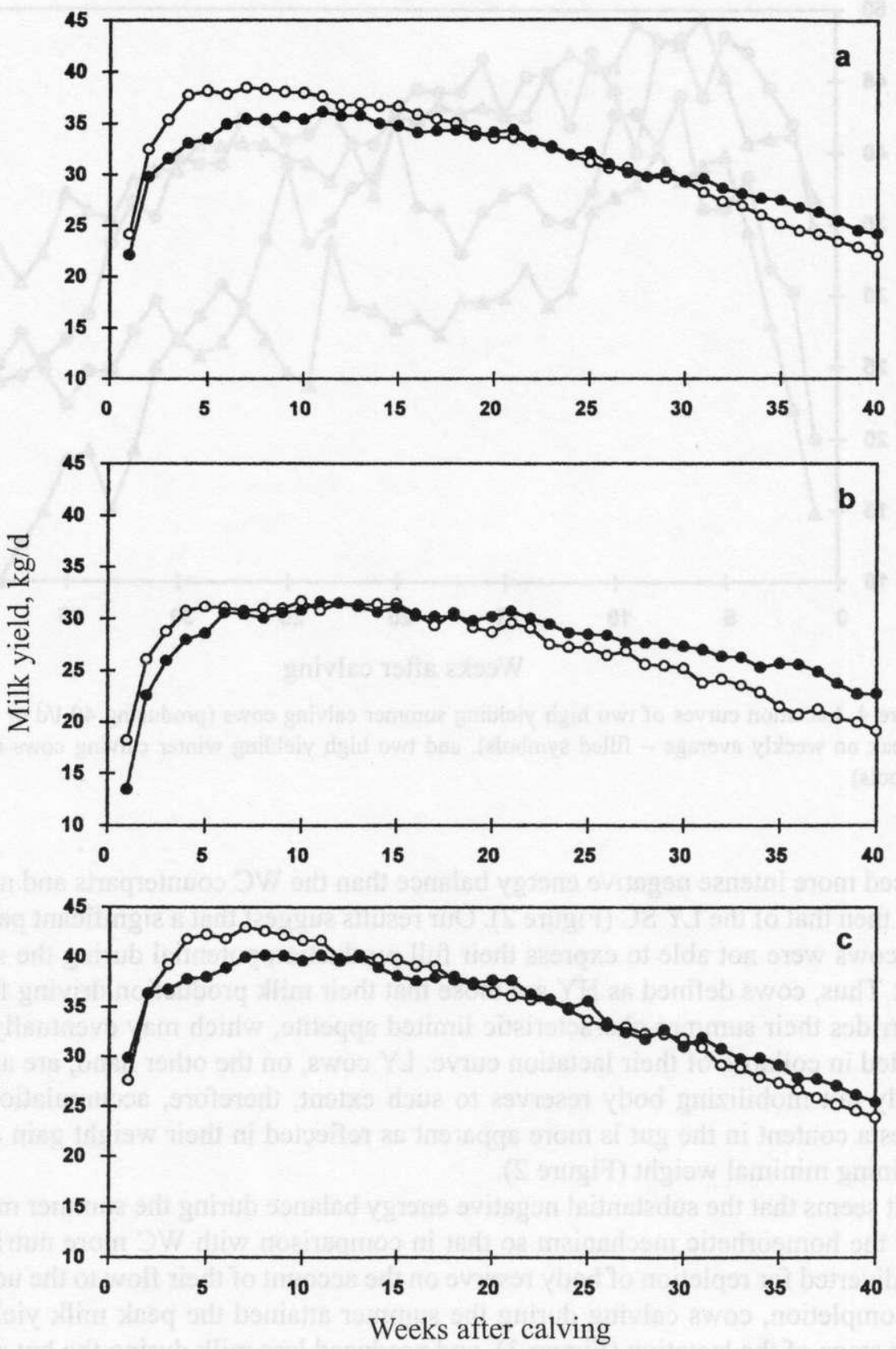

Figure 3. Lactation curves of summer (filled symbols) and winter (open symbols) calving cows. $\mathrm{a}$ - all cows, $\mathrm{b}$ - low potential cows yielding less then $40 \mathrm{l} / \mathrm{d}$ at peak on weekly average, $\mathrm{c}$ - high potential cows yielding $40 \mathrm{l} / \mathrm{d}$ or more at peak on weekly average 


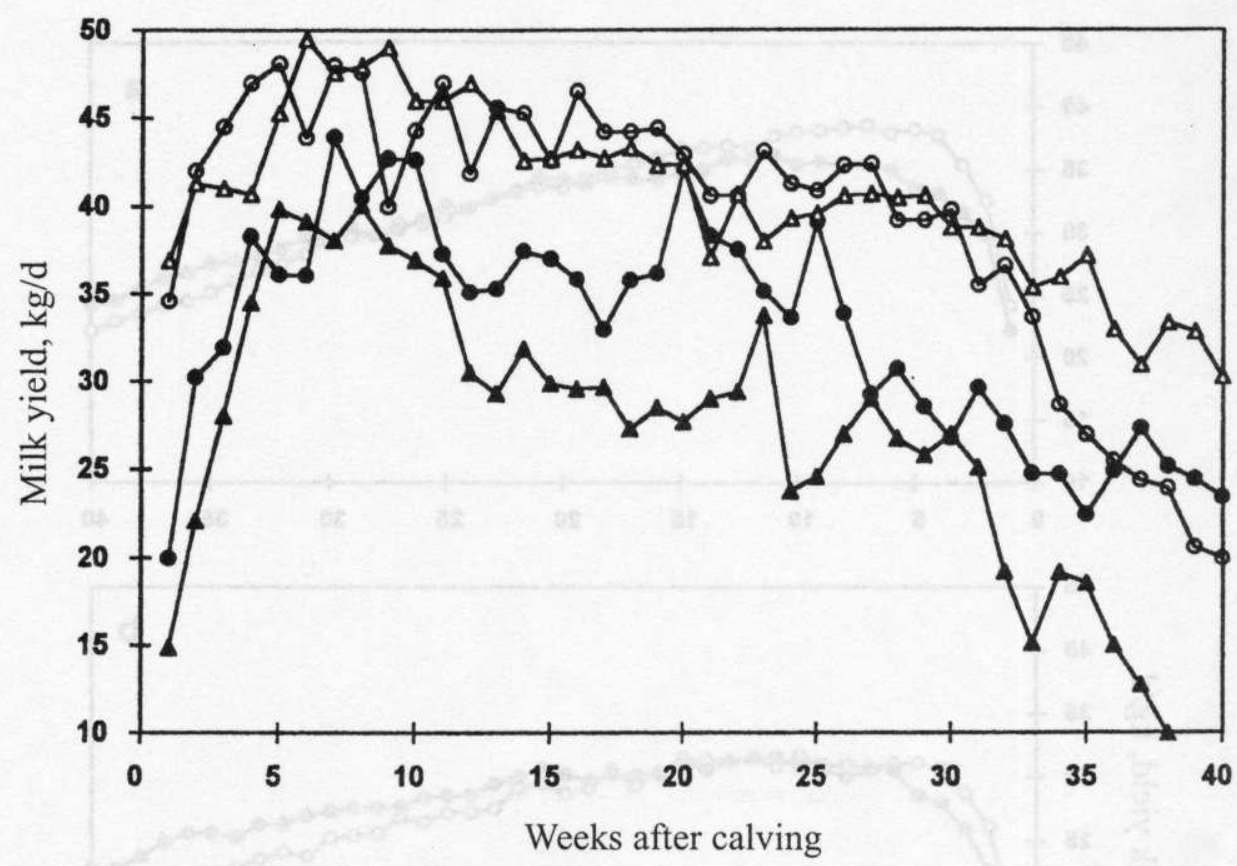

Figure 4. Lactation curves of two high yielding summer calving cows (producing $40 \mathrm{l} / \mathrm{d}$ or more at peak on weekly average - filled symbols), and two high yielding winter calving cows (open symbols)

ienced more intense negative energy balance than the WC counterparts and much less then that of the LY SC (Figure 2). Our results suggest that a significant part of the cows were not able to express their full production potential during the summer. Thus, cows defined as HY are those that their milk production driving force overrides their summer-characteristic limited appetite, which may eventually reflected in collapse of their lactation curve. LY cows, on the other hand, are apparently not mobilizing body reserves to such extent, therefore, accumulation of digesta content in the gut is more apparent as reflected in their weight gain after attaining minimal weight (Figure 2).

It seems that the substantial negative energy balance during the summer modified the homeorhetic mechanism so that in comparison with WC more nutrients are diverted for repletion of body reserve on the account of their flow to the udder. In completion, cows calving during the summer attained the peak milk yield at later stage of the lactation (Figure 3), and produced less milk during the hot summer months (Barash et al., 1996).

In a non-seasonal breeding system, the calving date of a given cow will fluctuate between seasons because of the break between two reproduction cycles. Thus, 
there is no reason to assume that the $\mathrm{SC}$ and $\mathrm{WC}$ represent two genetic populations in a given herd. The inability of the HY cow to attain their full genetic potential (i.e., the parallel winter records) if their parturition occurred during the summer may be related therefor to a non-recoverable retardation of their mammogenesis. The LY cows were able to attain their genetic potential, however, mammogenesis was apparently delayed in these cows in direct proportion to the delay in attaining their maximal milk yield.

During the second half of the lactation period, cows that calved during the summer enter the winter, and vise versa for cows that calved during the winter. The faster decrease in milk yield when the second half of the lactation occurred during the summer most likely reflects greater loss of parenchyma cell (Knight and Wilde, 1993), and therefore may be interpreted as acceleration of the involution process. Thus, it seems that heat stress also accelerates involution.

This study have shown for the first time evidence for negative interaction between heat stress and milk yield. In the LY cows the decline in potential MY during the period elapsing between parturition and peak lactation was compensated by the better persistency in MY during the post-peak period. This was not the case with HY cows for which the decline in potential MY during the period elapsing between parturition and peak lactation was not compensated by the better persistency in MY during the post-peak period. Fresh cows were more resistant to heat stress than multiparous cows (Barash et al., 1996). However, this unyielding to heat stress reflects most likely merely the consequence of their lower MY.

The physiological basis for the negative interaction between heat stress and MY could have been the result of a severe challenge to homeostasis regulation of body temperature (West, 1994), and plasma osmolality and ion concentration (Maltz et al., 1994; Bar-Peled et al., 1997). We found that the lactation curves of cows in early lactation approaching a yield of more then $40 \mathrm{l} /$ day frequently collapse and their lactation curve may differ substantially from those of similar WC (Figure 4), or from the SC averaged smooth patterns presented in Figure 3.

We have shown that heat stress during early lactation affects the entire lactation and BW curves in dairy cows. The effects are more pronounced in high producing cows. Therefore, any management strategy related to heat stress should take in account the effect over the entire lactation period as well as genetic potential for production. 


\section{REFERENCES}

Armstrong D.V., 1994. Heat stress interactions with shade and cooling. J. Dairy Sci. 77, 2044-2050 Bahaa A.O., Nombekela S.W., Murphy M.R., El-Newahy T., Drackley J.K., Spahr S.L., 1998a. Rumen function and metabolism of Holstein cows in early lactation. J. Dairy Sci. 78, Suppl. 1, 241 (Abstr.)

Bahaa A.O., Nombekela S.W., Murphy M.R., El-Newahy T., Drackley J.K., Spahr S.L., 1998b. Rumen function and metabolism of Holstein cows in early lactation. 1998 Illinois Dairy Reports Coop. Extention Service. Urbana, llinois

Bandanrannayaka D.D., Holmes C.W., 1976. Changes in the composition of milk and rumen contents in cows exposed to high ambient temperature with controlled feeding. Trop. Anim. Health Prod. 8, 38-44

Barash H., Silanikove N., Weller J.I., 1996. Effect of season of birth on milk, fat, and protein production of Israeli Holsteins. J. Dairy Sci. 79, 1016-1020

Bar-Peled U., Maltz E., Tagari H., Lehrer A.R., Robinson B., Voet H., Folman Y., Bruckental I., Gacitua H., Silanikove N., 1997. Effects of frequent machine milking and suckling in early lactation on blood plasma ion homeostasis in high-yielding dairy cows. J Agr. Sci. 129, $237-242$

Beede D.K., Collier R.J., 1986. Potential nutritional strategies for intensively managed cattle during thermal stress. J. Anim, Sci. 62, 543-554

Berman A., Fulman Y., Caim M., Mamean M., Herz Z., Wolfenson D., Arieli A., Graber Y., 1985. Upper critical temperatures and forced ventilation effects for high yielding dairy cows in sub. tropical climate. J. Dairy Sci. 68, 1488-1495

Collier R.J., Beede D.K., Thatcher W.W., Israel L.A., Wilcox C.J. 1982. Influences of environment and its modification on dairy animal health and production. J. Dairy Sci. 65, 2213-2227

Israel Cattle Breeders Association, 1997. Israel Holstein Herdbook. Hidekel Press Ltd.. Tel Aviv (Israel)

Knight C.H., Wilde C.J., 1993. Mammary cell changes during pregnancy and lactation. Livest. Prod. Sci. 35, 3-19

Kroll O., Fraiman A., Antler A., Maltz E., 1997. Cows transfer between feeding groups according to individual real time performance (in Hebrew). Meshek ha'Bakar ve'haHalav 266, 20-21

Maltz E., Devir S., Metz J.H.M., Hogeven H., 1997. The body weight of the dairy cow: I. Introductory study into body weight changes in dairy cows as a management aid. Livest. Prod. Sci. 48, $175-186$

Maltz E., Kroll O., Sagi R., Devir S., Spahr S.L., Genizi A., 1991. Milk yield, parity and cow potential as variables for computerized concentrates supplementation strategy. J. Dairy Sci. 74, $2277-2289$

Maltz E., Metz J.H.M., 1994. An individual approach to manage the dairy cow: a challenge for research and practice. International Symposium on Prospects for Future Dairying: A Challenge for Science and Industry. Alfa Laval Agri, Tumba (Sweden) and Swedish University of Agricultural Sciences, Uppsala (Sweden), pp. 267-282

Maltz E., Silanikove N., 1996. Kidney function and nitrogen balance in high yielding dairy cows at the onset of lactation. J. Dairy Sci. 79, 1521-1527

Maltz E., Silanikove N., Shalit U., Berman A., 1994. Diurnal fluctuations in plasma ions and water intake of dairy cows as affected by lactation in warm weather. J. Dairy Sci. 77, 2720-2726

National Research Council, 1989. Nutrient Requirements of Dairy Cattle. 6th revived Edition. National Academy of Science. Washington, DC

Peiper U., Edan Y., Devir S., Barak M., Maltz E., 1993. Aulomatic weighing of dairy cows. J. Agr. Eng. Res. 56, 13-24 
SAS, 1988. User's Guide: Statistics Cary, NC: SAS Institute

Wayman O., Johonson H.D., Merilan C.P., Berry I.L., 1962. Effect of ad libitum and force-feeding of two rations on lactating cows subjected to thermal stress. J. Dairy Sci. 45, 1472-1478

West J.W., 1994. Interactions of energy and bovine somatotropin with heat stress. J. Dairy Sci. 77, 2091-2102

\section{STRESZCZENIE}

Laktacja i masa ciała krów mlecznych: interakcje pomiędzy stresem cieplnym, okresem wycieleń i zdolnością produkcyjną

Interakcje pomiędzy stresem cieplnym, okresem wycieleń oraz produkcją mleka (MY) i ich wpływem na laktację i krzywe zmian masy ciała (BW) oznaczano na podstawie analizy dziennych MY i BW krów mlecznych. Krowy cielące się latem (SC) wcześniej osiągały minimalną BW niż

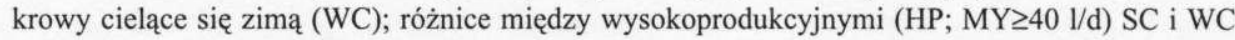
były większe niż różnice między krowami o niższej produkcyjności (LP; MY<40 1/d). Minimalne BW było niższe u wysokich SC niż WC, co mogło być związane $\mathrm{z}$ różnicami pomiędzy krowami HP. Szczyt wydajności mleka był wyższy u wszystkich WC niż wszystkich SC, podobny u krów LP w obydwóch grupach, i wyższy u krów wysokoprodukcyjnych WC niż SC. Różnice $(4,4 \%)$ w wydajności mleka w pierwszych 40 tygodniach po wycieleniu pomiędzy wszystkimi krowami WC (8960 l) a wszystkimi SC $(8568$ l) odpowiadały różnicy $(8,0 \%)$ pomiędzy wysokoprodukcyjnymi WC (10444 1) a wysokoprodukcyjnymi SC (9604 1). Latem szczyt wydajności mleka występował później niż zimą, niezależnie od wysokości produkcji.

Wykazano, że stres cieplny we wczesnej laktacji wpływa na całą laktację i przebieg zmian w BW krów mlecznych, a także ujemnie oddziaływuje na MY. 